\title{
A Comprehensive Review of the Management of Pregnant Women with COVID-19: Useful Information for Obstetricians
}

\author{
Feng Guo' \\ Xiuhua Yang (iD ${ }^{2}$ \\ 'Department of Emergency Medicine, \\ Shengjing Hospital of China Medical \\ University, Shenyang, Liaoning, People's \\ Republic of China; ${ }^{2}$ Department of \\ Obstetrics, The First Hospital of China \\ Medical University, Shenyang, Liaoning, \\ People's Republic of China
}

\begin{abstract}
Due to the physiological changes of the cardiovascular system and respiratory system in pregnancy, pregnant women are vulnerable to pathogen infection and severe pneumonia. With the increasing incidence of COVID-19 pneumonia, its influence on pregnant women and neonates has attracted more attention. In this review, we collected all relevant articles published in English from September 1, 2019 to June 10, 2021, regarding the epidemiology, clinical presentations, chemical examinations, imaging findings, the timing of delivery and delivery mode, maternal and neonatal complications, medication, and vertical transmission of COVID-19 in pregnancy. It has been reported that compared with nonpregnant females, pregnant women with COVID-19 are more likely to develop into severe type. In particular, the risk of entering the intensive care unit and endotracheal intubation was higher. Chest computed tomography and blood routine examination are useful for the diagnosis of COVID-19 in a short period of time. COVID-19 pneumonia is not an independent indication for terminating the pregnancy, and it is not contraindicated for vaginal delivery. Compared to normal pregnant females, patients with COVID-19 showed an elevated susceptibility of preterm delivery. Multidisciplinary consultation was suggested in the treatment policy of COVID-19 in pregnancy. Currently, there is no evaluation on the safety, efficacy, and immunity of the approved vaccines for mothers and infants. In human placental tissues, the COVID-19 virus has been found by different detection methods. The mechanism by which the virus enters the placental tissue is unclear, which may be related to placental inflammation. The long-term prognosis of pregnant women with COVID-19 remains unclear and requires further detailed investigation.
\end{abstract}

Keywords: pregnant, COVID-19, SARS-CoV-2, neonate, vertical transmission

\section{Introduction}

The novel coronavirus disease (COVID-19) caused by severe acute respiratory syndrome coronavirus 2 (SARS-CoV-2) has gradually spread in many countries. Up to June 15, 2021, there were 116,665 cases of COVID-19 in China. Among these patients, 5306 deaths (4.5\%) were identified. In the world, 175,987,176 individuals have been infected with COVID-19, and 3,811,561 people died of this disease as of June 15, 2021, according to the statistics of the World Health Organization (WHO).

Gene sequencing found that COVID-19 belonged to the subgenus Sarbecovirus. ${ }^{1}$ The diameter of SARS-CoV-2 is approximately 50-200 nm with a single-chain RNA genome. ${ }^{2}$ In terms of genome composition, the similarity of
Correspondence: Xiuhua Yang Department of Obstetrics, The First Hospital of China Medical University, Shenyang, Liaoning, People's Republic of China

Email yangxiuhuajing@hotmail.com 
COVID-19 with severe acute respiratory syndrome coronavirus (SARS) and Middle East respiratory syndrome coronavirus (MERS) is $80 \%{ }^{3}$ and $50 \%,{ }^{1}$ respectively. COVID-19 can be highly contagious through air foam from the respiratory tract, aerosols in confined spaces, and close contact, and it can be transmitted from one person to another. ${ }^{4}$ The clinical manifestations of the disease vary from mild to severe. A large study of 44,672 patients showed that $81 \%$ of the cases were mild (mild symptoms), $14 \%$ (imaging examination indicates that over half of the lungs are involved within 1-2 days) were severe, and the remaining 5\% were critical (multiple organ dysfunction or need tracheal intubation). ${ }^{5}$ The general mortality rate of COVID-19 was $2.3 \% .^{5}$ Although most patients are mild, for those with high-risk factors, many patients need to enter the intensive care unit (ICU) for treatment and may die. ${ }^{6}$

At a time when COVID-19 is rapidly spreading, obstetricians should be aware of the clinical manifestations, principles of management, and prognosis of the disease during pregnancy and postpartum. Hence, the purpose of this review was to collect updated reports regarding the epidemiology, clinical presentations, chemical examinations, imaging findings, timing of delivery and delivery mode, maternal and neonatal complications, medication, and vertical transmission of COVID-19 in pregnancy.

\section{Data Collection}

Two independent researchers searched the articles in PUBMED with the following medical subject headings (MeSHs): “COVID-19", "SARS-CoV-2", “pregnant", "neonate", or "vertical transmission". All articles were published in English from September 1, 2019 to June 10, 2021.

\section{Physiological and Immunological Changes in Pregnancy}

Due to the physiological changes of the cardiovascular system and respiratory system in pregnancy, pregnant women are vulnerable to pathogen infection and severe pneumonia. Pregnant women have increased heart rate, more blood volume, decreased lung volume, elevated diaphragm, increased oxygen consumption, and edematous respiratory tract mucosa. Changes in lung volume and vasodilation result in airway edema and elevated respiratory secretions. Therefore, pregnant women have poor tolerance for hypoxia. ${ }^{7}$ Besides, pregnant women show specific immune status that can tolerate the semiallogeneic fetus. ${ }^{8}$ Due to the effect of suppressive $\mathrm{T}$ cells, pregnant women have transient immunosuppression, so they are more susceptible to virus infection. ${ }^{9,10}$ Furthermore, changes in cell-regulated immunity make pregnant women more vulnerable to intracellular pathogens, including viruses. ${ }^{11}$ Dysfunction of elements such as cytokines and the complement system caused by viruses also have adverse effects on the growth of the neonatal brain. ${ }^{12}$ In patients with COVID-19 infection, $\mathrm{T}$ helper (Th) 17 immunity was found to be significantly increased, resulting in the release of numerous inflammatory cytokines. ${ }^{13,14}$ Fetuses born from infected pregnant women may be in an inflammatory state promoted by placental sample or systemic immune response from their mothers. The Treg/Th17 immune balance is very important for normal pregnancy. ${ }^{15,16}$ If Treg cells decrease and Th17 cells increase, it may cause recurrent pregnancy loss, preeclampsia and preterm birth. ${ }^{13,17-19}$ Accordingly, it can be concluded that the immune inflammatory reaction of COVID-19 infection may lead to many obstetrical complications, resulting in short- and long-term adverse maternal and fetal outcomes.

\section{SARS and Pregnancy}

SARS infection during pregnancy may cause many pregnancy complications, such as spontaneous abortion, fetal growth restriction, and premature delivery, and pregnant women with SARS had worse consequences compared with non-pregnant women. ${ }^{20-23}$ During the SARS epidemic in 2002-2003, 12 pregnant women were infected with SARS in a report. ${ }^{20}$ Seven women were infected in the first trimester, and four of them (57\%) had a spontaneous abortion. Among the five pregnant women who were infected in the second and third trimester, 2 cases $(40 \%)$ had fetal growth restriction, 4 cases $(80 \%)$ had premature delivery ( 1 baby was born naturally, 3 cases had induced labor due to severe complications of mothers). In total, three of the twelve died. ${ }^{20}$ Furthermore, some studies have found that there was SARS virus in peritoneal fluid of 28 cases of pregnant women during cesarean section through the detection of Reverse Transcription-Polymerase Chain Reaction (RTPCR) ${ }^{24}$ which suggested that obstetricians should shorten the operation time and reduce the chance of contact between neonate and maternal blood or body fluid during cesarean section. It was gratifying to note that during the SARS epidemic, there were no reports of neonatal vertical 
infection with SARS-CoV. ${ }^{21,24-26}$ However, breastfeeding was not recommended for pregnant women with SARS to avoid potential neonatal infection.

\section{MERS and Pregnancy}

MERS is another coronavirus that can lead to severe pneumonia. The first case occurred in Saudi Arabia in 2012, subsequently, the disease gradually spread to 27 countries. $^{27}$ There are few reports of MERS in pregnant women. In a review including 11 pregnancies with MERS, $10(91 \%)$ had poor pregnancy outcomes, 6 newborns (55\%) needed to be admitted to the neonatal intensive care unit (NICU), ${ }^{6}$ and 3 (27\%) maternal deaths were recorded. ${ }^{28}$ Due to severe respiratory failure of mothers, two newborns were born prematurely. ${ }^{28}$ During the outbreak of MERS in Jordan in 2012, there was a stillbirth in a pregnant woman with five months of gestation due to MERS infection. ${ }^{29}$ In Korea, a pregnant female was infected with MERS in the third trimester. ${ }^{30}$ Although she had vaginal bleeding and premature rupture of membranes, she successfully delivered a live fetus by cesarean section at full-term and recovered completely. ${ }^{30}$ No antibody (IgG, IgM, or IgA) was found in the blood of the newborn, indicating that there was no proof of vertical transmission of MERS from mother to infant, ${ }^{30}$ which was consistent with other reports. ${ }^{21}$

\section{Clinical Manifestations of COVID-I9 in Pregnancy}

When COVID-19 pneumonia attacks, fever and cough are the common symptoms, other symptoms, such as myalgia, shortness of breath, discomfort, diarrhea, sore throat, can also appear, but not common. ${ }^{31,32}$ It was worth noting that $56 \%$ of pregnant females with COVID-19 infection might have normal body temperature and atypical clinical manifestations. ${ }^{33}$ Farida Elshafeey et al $^{34}$ assessed 385 pregnant women with COVID-19 infection with data collected from 33 studies and concluded that patients with mild disease accounted for the largest proportion, followed by those with severe disease and then those in critical condition, with the percentages of $95.6 \%, 3.6 \%$, and $0.8 \%$, respectively. Seventeen women were sent to ICU, 6 women received mechanical ventilation, and 1 woman died. ${ }^{34}$ Studies have shown that pregnancy regulates the immune system, and HCG and progesterone inhibit Th1 pro-inflammatory pathway by reducing tumor necrosis factor- $\alpha(\mathrm{TNF}-\alpha){ }^{35}$ We hypothesized that this regulation of the immune system might prevent pregnant women from cytokine storm syndrome and lower morbidity and mortality. This could interpret the relatively optimistic outcomes of 385 women in 33 reports. ${ }^{34}$ A report from France included 617 pregnant women with COVID-19. ${ }^{36}$ Among these patients, 35 of them $(5.7 \%$; 95\% CI 4.0-7.8) belonged to the severe group, and one pregnant woman died $(0.2 \%) .{ }^{36}$ A newborn died of premature birth. ${ }^{36}$ The incidence of preterm birth was related to the severity of the maternal condition. ${ }^{36}$ Since COVID-19 may lead to severe and fatal respiratory distress, pregnant females with primary diseases may benefit from the lockdown policy. ${ }^{36}$ Furthermore, a study from the UK included 1148 pregnant women with SARS-CoV-2, $63 \%$ of the patients had symptoms. ${ }^{37}$ Compared with pregnant women without SARS-CoV-2, Black, Asian and other ethnic minorities were more likely to suffer from this virus. ${ }^{37}$ Pregnant women with symptoms had a higher possibility of entering the ICU for treatment (aOR 57.67, (7.80-426.70)), but the risk of adverse prognosis was relatively low. ${ }^{37}$ The rate of cesarean section and neonatal NICU admission were elevated regardless of symptom condition. ${ }^{37}$ According to this report, most pregnant women infected with SARSCoV-2 did not have serious complications. ${ }^{37}$ Another large sample report included 4005 pregnant women with suspected or confirmed COVID-19 infection from the UK and the United States. ${ }^{38}$ Patients with SARS-CoV-2 had a higher incidence of premature delivery compared with normal pregnant women in the same period. ${ }^{38}$ The prevalence of stillbirth, small for gestational age (SGA), and early neonatal death was comparable to that of normal pregnant women. ${ }^{38}$ Although the probability of maternal death was low, it was higher than the expected data in the UK and the United States. ${ }^{38}$ The reason may be related to the lack of awareness of asymptomatic patients. ${ }^{38}$ These data provide strong evidence supporting the prevention of COVID-19 infection during pregnancy, especially the increased incidence of premature birth and maternal death, which further clarify the necessity of vaccination for pregnant women and females planning pregnancy. ${ }^{38}$

A meta-analysis including 192 studies reported that compared with females who are not pregnant, pregnant women are less likely to have symptoms after COVID19 infection. ${ }^{39}$ However, pregnant women had a higher risk to receive ICU treatment (OR: 2.13, 1.53-2.95; $\mathrm{I}^{2}=$ 71.2\%), endotracheal intubation (OR: 2.59, 2.28-2.94; $\mathrm{I}^{2}=$ $0 \%$ ), and extracorporeal membrane oxygenation (ECMO) (OR: $\left.2.02,1.22-3.34 ; \mathrm{I}^{2}=0 \%\right) .{ }^{39}$ In this report, $0.02 \%$ of 
pregnant women with COVID-19 died for various reasons. ${ }^{39}$ Another meta-analysis included 24 studies involving 1100 pregnant women. ${ }^{40}$ The incidence of pneumonia was $89 \%{ }^{40} 8 \%$ of the patients were admitted to the ICU. ${ }^{40}$ Three stillbirths occurred and five pregnant women died. $^{40}$ The cesarean section rate for these pregnant women was $85 \%$, although most of them had no clear indication for cesarean section. ${ }^{40}$ Besides, a systematic review collected 13 studies including 462 pregnant women with COVID-19. ${ }^{41}$ Maternal ICU occupancy rate was $3 \%, 1.4 \%$ of the patients were critically ill, no maternal deaths were demonstrated, and the incidence of preterm birth was $20.1 \%{ }^{41}$ Only one of the 313 newborns died. ${ }^{41}$ Another systematic review analyzed 24 studies, including 324 pregnant women with COVID-19. ${ }^{42}$ The incidence of severe cases was $0-14 \%$ among different reports. ${ }^{42}$ Almost all of the patients had positive pulmonary imaging findings. ${ }^{42}$ The cesarean section rate was $78 \%$ among these patients, and 4 pregnant women had miscarriages. ${ }^{42}$

It has been reported that some factors, such as obesity, diabetes, hypertension, primary maternal diseases, and advanced age, are related to severe COVID-19 in pregnant women in China, the United States, France, and the $\mathrm{UK}^{36,37,39,43-46}$ A number of high risk factors of preeclampsia are consistent with those of severe COVID-19. ${ }^{46}$ Some patients with severe COVID-19 showed similar symptoms to preeclampsia, but there was no significant change in the markers related to preeclampsia (fms-like tyrosine kinase-1 and placental growth factor), indicating that COVID-19 could induce systemic inflammation similar to preeclampsia, but COVID-19 was not caused by poor placentation. ${ }^{47,48}$ It should be noted that COVID-19 may aggravate the hypercoagulable state of pregnant women, resulting in lower fetal vascular perfusion and excessive placental fibrin deposition. ${ }^{49,50}$

Pregnant women with COVID-19 may be asymptomatic during pregnancy, but diagnosed after delivery. The hormone level of pregnant women in postpartum had a significant change, and the steroid hormone dropped sharply. ${ }^{51}$ The immune cells (hemophagocytes, natural killer (NK) cells, dendritic cells (DCs), and T cells) in postpartum also altered significantly, compared with the late pregnancy. ${ }^{52}$ These hormonal and immunological changes may lead to the susceptibility of SARS-CoV-2 infection in postpartum. However, the mortality rate was not increased. ${ }^{53-56}$ In the future, we need to closely follow up pregnant women with COVID-19 after delivery to collect more valuable data. These experimental results are conducive to the formulation of compatible health care policies, and may help obstetricians to make appropriate treatments during the epidemic period.

\section{Psychological Distress During COVID-I 9 Pandemic}

During the COVID-19 epidemic, many pregnant women showed depression and anxiety. ${ }^{57,58}$ Pregnant women with depression and anxiety were more likely to suffer from insomnia. ${ }^{59}$ The content of cortisol in plasma and amniotic fluid increased significantly among pregnant women with anxiety. ${ }^{60}$ Depression and anxiety in pregnancy may lead to preeclampsia, gestational diabetes, premature delivery, low birth weight, and postpartum depression. ${ }^{60,61}$ Previous reports have also shown that perinatal depression and anxiety may also cause abortion, neonatal asphyxia, and fetal brain dysfunction. ${ }^{62-64}$ Children born to females with increased stress may also have mental developmental disorders. ${ }^{65}$ These short-term and long-term adverse effects of COVID-19 infection on pregnant women and fetuses deserve physicians' concern.

\section{Diagnosis and Imaging of COVID-I 9 in Pregnancy}

There were some abnormal laboratory indicators in pregnant women with COVID-19, such as increased C-reactive protein (6/9), elevated alanine aminotransferase (ALT) and aspartate aminotransferase (3/9), ${ }^{46}$ and lymphopenia $(5 / 9) .{ }^{31}$ In one study, 118 pregnant women with COVID19 were collected in Wuhan. ${ }^{66}$ Among them, 84 (71\%) were positive by PCR assay, and 34 (29\%) were diagnosed as lung computed tomography (CT) lesions. ${ }^{66}$ It is relatively difficult to diagnose COVID-19 for pregnant women due to physiological leukocytosis and elevated neutrophil ratio during pregnancy. In COVID-19 patients, eosinopenia occurred in the early stage of fever, and the decrease of eosinophils was significant. ${ }^{67}$ Lymphopenia was considered to be of great significance in the diagnosis of COVID$19,{ }^{31}$ but rarely occurred in pregnant women. ${ }^{68}$ Therefore, eosinopenia may be used as one of the early diagnostic indicators. It has been discovered that glucocorticoids may cause eosinopenia, ${ }^{69}$ which can be inferred that COVID19 could affect the release of endogenous glucocorticoids in vivo.

With the help of RT-PCR, lung CT can be used to diagnose COVID-19, showing the sensitivity of $97 \%$, 
specificity of $25 \%$, positive predictive value of $65 \%$, and negative predictive value of $83 \% .^{70}$ Since lung CT has a vital role in the diagnosis of COVID-19 in pregnant women, and the risk is relatively small, it is suggested that pregnant women should take lung CT examination after signing the consent form. During the process of the CT examination, the abdomen can be shielded, and the examination time should be reduced to lower the radiation exposure of the fetus. Laboratory tests such as RT-PCR need a certain amount of time, but maternal delivery is impending. For patients with atypical or mild symptoms, rapid lung $\mathrm{CT}$ test and blood routine examination are more useful for the diagnosis of COVID-19 in a short period of time. Early diagnosis is helpful to protect other normal pregnant women and medical workers.

\section{The Timing of Delivery and Delivery Mode of Pregnant Women with COVID-I 9}

According to the specialists' suggestions from the Chinese Medical Association (CMA), ${ }^{71}$ COVID-19 pneumonia is not a strong indication for terminating a pregnancy, and the time of ending pregnancy needs to be determined according to the specific condition of each patient. The main considerations are maternal physical condition, gestational weeks, and the intrauterine situation of the fetus. If the maternal condition is stable, the timing of delivery depends on the gestational weeks. If the type of COVID-19 pneumonia is severe or critical (according to the edition reported), ${ }^{72}$ earlier delivery should be considered even though the gestational age is very small. Many studies have shown that the conditions of severe or critical patients could be significantly improved after the termination of pregnancy. ${ }^{72}$

As for the mode of delivery, cesarean section was conducted in most of the reports, and fetal distress was the main reason for the surgery. ${ }^{31,33,73}$ However, there were still some cases of vaginal delivery, with good pregnancy results. ${ }^{31,33}$ Most guidelines and expert recommendations pointed out that COVID-19 pneumonia is not contraindicated for vaginal delivery. ${ }^{74,75}$ Clinically, if a puerpera needs to have a cesarean section, it is better to be done by a qualified obstetrician to reduce the possibility of complications and shorten the operation time. In the process of cesarean section, doctors need to pay attention to reduce the bleeding to maintain hemodynamic stability and decrease the cardiopulmonary burden caused by blood transfusion. In the process of delivery, related samples (including amniotic fluid, umbilical cord blood, placenta, vaginal secretions, and neonatal throat swabs) should be sent to test the SARS-COV-2 virus, to determine whether vertical transmission occurred.

\section{Anesthesia During Cesarean Section for Pregnant Women with COVID-I 9}

Epidural or general anesthesia can be applied in cesarean section for pregnant women with COVID-19. ${ }^{23}$ Most anesthesiologists prefer epidural anesthesia since it can avoid infection caused by endotracheal intubation, as well as avoid the respiratory depression and decline of neonatal muscle tension caused by general anesthesia. If the complication of COVID-19 occurs, such as kidney failure or disseminated intravascular coagulation, invasive monitoring should be considered, including central venous catheterization. ${ }^{76}$ It is essential to perform anesthesia by skillful anesthesiologists to reduce the duration of operation and needless contact with the virus. In the process of endotracheal intubation, anesthesiologists must use intact personal protective equipment (PPE) to avoid infection.

\section{Maternal and Neonatal Complications Among Pregnant Women with COVID-I 9}

COVID-19 did not seem to elevate the incidence of preeclampsia. ${ }^{31}$ Compared with COVID-19 patients without preeclampsia, the prognosis for patients with preeclampsia was not worse. ${ }^{31}$ For pregnant women with COVID-19, the incidences of premature rupture of membranes and spontaneous miscarriage did not increase compared with normal pregnant women in early reports. ${ }^{31}$ However, Allotey et al reported that the rate of premature birth in pregnant women with COVID-19 was $6 \% .{ }^{39}$ Similarly, compared to normal pregnant females, patients with COVID-19 showed a higher risk for preterm delivery (OR: 1.47, 95\% CI: 1.14-1.91; $\mathrm{I}^{2}$ $=18.6 \%) .{ }^{39}$ Recently, Dubey et al conducted a metaanalysis and revealed that $27 \%$ of pregnant women with COVID-19 showed adverse pregnancy outcomes, including preterm delivery, fetal vascular hypo-perfusion, and premature rupture of fetal membranes. ${ }^{77}$ The cesarean section rate of patients with COVID-19 was significantly increased (67.2-94\%), and the rate of vaginal delivery was just $6-32.8 \%$. $^{78-82}$

Ten percent of newborns with mothers with COVID19 showed fetal growth restriction. ${ }^{83}$ Yoon et $\mathrm{al}^{81}$ made 
a systematic analysis of the prognosis of 201 neonates whose mothers were COVID-19 positive. Between 36-48 hours after birth, $2.4 \%$ (4/167) of newborns were tested to be positive for COVID-19. ${ }^{81}$ The four COVID-19 positive newborns were all delivered by cesarean section with typical pneumonia imaging on chest X-ray. ${ }^{81}$ One week later, the four RT-PCR results of nasopharyngeal were negative, and they all recovered well. ${ }^{81}$ It has been reported that the neonatal survival rate was about $65 \%$ in pregnant women who were treated with ECMO for different reasons. ${ }^{84} \mathrm{Up}$ to now, in public data related to COVID-19, most pregnant women gave birth within 2 weeks of onset. It is not clear whether COVID-19 pneumonia affects fetal development in the subsequent pregnancy. Studies about perinatal complications were summarized in Table 1.

Table I Included Studies About Perinatal Complications

\begin{tabular}{|c|c|c|c|c|}
\hline Studies & $\begin{array}{l}\text { Research } \\
\text { Type }\end{array}$ & $\begin{array}{l}\text { Number of } \\
\text { Mothers/ } \\
\text { Neonates }\end{array}$ & Maternal Outcomes & Neonatal Outcomes \\
\hline Chen et $\mathrm{al}^{31}$ & $\begin{array}{l}\text { Retrospective } \\
\text { study }\end{array}$ & $9 / 9$ & $\begin{array}{l}\text { No pregnant women developed } \\
\text { pneumonia. No patients died. }\end{array}$ & Nine newborns survived without asphyxia. \\
\hline Elshafeey et $\mathrm{al}^{34}$ & $\begin{array}{l}\text { Systematic } \\
\text { review }\end{array}$ & $385 / 256$ & $\begin{array}{l}\text { I7 pregnant females had ICU admission. } \\
\text { One female died. }\end{array}$ & $\begin{array}{l}\text { There were two cases of intrauterine fetal } \\
\text { death, and one neonate died. }\end{array}$ \\
\hline Kayem et $\mathrm{al}^{36}$ & $\begin{array}{l}\text { Retrospective } \\
\text { study }\end{array}$ & $617 / \mathrm{NA}$ & $\begin{array}{l}\text { The incidence of preterm birth was between } \\
\text { 10.6-79.3\%. One pregnant woman died. }\end{array}$ & One neonate died. \\
\hline Vousden et $\mathrm{al}^{37}$ & $\begin{array}{l}\text { Prospective } \\
\text { study }\end{array}$ & II 48/NA & $\begin{array}{l}\text { Symptomatic patients were more likely to } \\
\text { have ICU admission, but the overall } \\
\text { incidence of adverse outcomes was low. }\end{array}$ & $\begin{array}{l}\text { The admission of NICU increased } \\
\text { regardless of symptom condition. }\end{array}$ \\
\hline Allotey et $\mathrm{al}^{39}$ & $\begin{array}{l}\text { Systematic } \\
\text { review and } \\
\text { meta-analysis }\end{array}$ & $67,27 I / 9466$ & $\begin{array}{l}\text { Compared with non-pregnant females, } \\
\text { pregnant women with COVID-19 were } \\
\text { more likely to have preterm delivery, ICU } \\
\text { admission and maternal death. }\end{array}$ & $\begin{array}{l}\text { The neonates were more likely to enter } \\
\text { NICU compared with those born from } \\
\text { non-pregnant females. }\end{array}$ \\
\hline Dubey et $\mathrm{al}^{77}$ & $\begin{array}{l}\text { Systematic } \\
\text { review and } \\
\text { meta-analysis }\end{array}$ & $790 / 548$ & $\begin{array}{l}\text { The proportions of cesarean section, } \\
\text { premature delivery, low birth weight, and } \\
\text { adverse pregnancy complications were } \\
\text { considered as } 72 \%, 23 \%, 7 \% \text {, and } 27 \% \text {. }\end{array}$ & One newborn died. \\
\hline Yan et $\mathrm{al}^{80}$ & $\begin{array}{l}\text { Retrospective } \\
\text { study }\end{array}$ & $116 / 100$ & $\begin{array}{l}6.9 \% \text { of the patients had severe pneumonia. } \\
\text { There was no maternal death, and the } \\
\text { incidence of preterm birth was } 21.2 \% \text {. }\end{array}$ & One newborn died. \\
\hline Yoon et $\mathrm{al}^{81}$ & $\begin{array}{l}\text { Systematic } \\
\text { review }\end{array}$ & $223 / 201$ & The incidence of preterm birth was $25.9 \%$. & $\begin{array}{l}\text { The incidences of small for gestational age } \\
\text { and low birth weight were } 8.3 \% \text { and } 15.6 \% \text {. }\end{array}$ \\
\hline Di et al ${ }^{40}$ & $\begin{array}{l}\text { Systematic } \\
\text { review and } \\
\text { meta-analysis }\end{array}$ & $1100 / 444$ & $\begin{array}{l}89 \% \text { of the patients developed pneumonia, } \\
8 \% \text { received ICU treatment, and } 5 \text { pregnant } \\
\text { women died. }\end{array}$ & $\begin{array}{l}\text { The NICU occupancy rate associated with } \\
\text { infection was } 2 \% \text {, and } 3 \text { newborns died. }\end{array}$ \\
\hline Huntley et $\mathrm{al}^{41}$ & $\begin{array}{l}\text { Systematic } \\
\text { review }\end{array}$ & $538 / 313$ & $\begin{array}{l}\text { Maternal ICU admission occurred in } 3.0 \% \text { of } \\
\text { cases. No maternal deaths were reported. } \\
\text { The preterm birth rate was } 20.1 \% \text {. }\end{array}$ & One neonate died. \\
\hline Juan et al ${ }^{42}$ & $\begin{array}{l}\text { Systematic } \\
\text { review }\end{array}$ & $324 / 221$ & $\begin{array}{l}\text { Four pregnant women experienced } \\
\text { spontaneous abortion. }\end{array}$ & $\begin{array}{l}\text { Eight newborns showed low birth weight. } \\
\text { About one third of newborns were } \\
\text { admitted to NICU. One newborn had } \\
\text { asphyxia and one newborn died. }\end{array}$ \\
\hline
\end{tabular}

Abbreviations: ICU, intensive care unit; NICU, neonatal intensive care unit; NA, non-analyzed. 


\section{Medication of Pregnant Women with COVID- I 9}

The fundamental treatment policies of COVID-19 in pregnancy are as follows: immediate segregation, detection for SARS-CoV-2, oxygen inhalation, reduction of excessive liquid input, fetal intrauterine observation, timely auxiliary ventilation if the respiratory failure occurs, choosing the appropriate mode of delivery, and multidisciplinary collaboration. Anticoagulants are often used to prevent thrombosis during cardiopulmonary bypass; however, placental hemorrhage may occur during this process. The establishment of ECMO needs multidisciplinary consultations, which is suggested to be carried out in a tertiary hospital.

There is an interaction between the surface glycoprotein of SARS-CoV-2 and angiotensin-converting enzyme 2 (ACE2) of epithelium in the patient's respiratory tract. The appearance of ACE2 in alveolar type 2 cells is the main lung characteristic. The combination between the virus and ACE2 may lead to hypertension in patients with COVID19 pneumonia, ${ }^{85}$ which is easily misdiagnosed as preeclampsia for pregnant women. Besides, if the result of D-dimer in a non-pregnant patient with COVID-19 was more than $1 \mathrm{mg} / \mathrm{mL}$, the mortality was high. ${ }^{86}$ Nevertheless, the levels of D-dimer are difficult to explain since these values are frequently elevated during pregnancy, and according to the traditional thresholds, only $84 \%, 33 \%$, and $1 \%$ of women in the early, middle, and late stages of pregnancy have normal D-dimer values. ${ }^{76}$ Corticosteroids are not recommended for patients with mild or atypical symptoms, unless the pregnant woman is likely to give birth before 34 weeks. ${ }^{87}$ It has been reported that the incidence of thrombosis in ICU patients with COVID-19 is increased. ${ }^{88}$ Combined with the hypercoagulable state in the maternal body, it is strongly recommended to give anticoagulant drugs at therapeutic doses for severe pregnant women with COVID-19.

The latest data has discussed the efficacy of remdesivir and chloroquine in the treatment of COVID- $19 .{ }^{89}$ At present, researchers in the United States and China are in full swing to carry out phase three experiments to evaluate the effect of remdesivir on COVID-19. Since the randomized controlled trials did not include pregnant women, it is not recommended to use remdesivir outside of an experimental setting. ${ }^{90}$ Chloroquine phosphate was mainly applied in the treatment of malaria, and it has the abilities of antivirus and immunomodulation. It can promote cell fusion through increasing intracellular $\mathrm{pH}$ value and interfering with glycosylation of cell receptors of the SARS virus in cell lines, thus blocking COVID-19 infection. ${ }^{89}$ Chloroquine and its products of metabolism can pass through the placenta. However, it can be securely applied in different stages of pregnancy without harmful effects on mothers and neonates. ${ }^{19}$ Pharmacokinetic reports showed that the concentration of chloroquine in plasma of pregnant woman was obviously reduced due to the extensive infiltration all through the body, ${ }^{91}$ resulting in the necessity of the increase of dosage for pregnant women with COVID-19 (about $500 \mathrm{mg}$ two times a day). ${ }^{92}$ It should be noted that too much chloroquine can cause low blood pressure, which is a burden for pregnant women with supine hypotension syndrome already. In addition, pregnant women should be fully aware of the possibility of impaired fetal growth affected by the use of alpha interferon in the first trimester. Due to the complex clinical condition of COVID-19 in pregnancy, a multidisciplinary team is necessary to evaluate and treat patients individually and carefully. Concerned specialists include obstetricians, infectious physicians, respiratory doctors, cardiologists, pediatricians, anesthesiologists, and ICU physicians.

Many guidelines recommend to provide COVID-19 vaccines for pregnant women. ${ }^{93}$ However, there is no evaluation on the safety, efficacy, and immunity of the approved vaccines for mothers and infants. At present, the widely used COVID-19 mRNA vaccines are not live vaccines, and there is no adjuvant. The benefits of vaccines in pregnant women are obvious. ${ }^{94}$ According to the results, the vaccine can protect the general population from laboratory confirmed infection and mild symptomatic COVID-19 infection 7-14 days after injection with an effective rate of $94-95 \% .{ }^{95}$ Moreover, in other vaccine studies, the protection rate of pregnant women and nonpregnant women is close. ${ }^{96,97}$ Therefore, the vaccine may have a similar effective function for pregnant women. ${ }^{98}$ The IgG produced by the vaccine may be transmitted to neonates through breastfeeding, which has a certain protective effect on their children. ${ }^{99}$ Obstetricians need to pay close attention to the experimental results of vaccines for pregnant women.

A recent meta-analysis included 1239 pregnant women infected with COVID-19 from 66 studies. ${ }^{100}$ The authors found that among moderate-risk patients, the percentage of receiving oxygen inhalation, antibiotics, antiviral drugs and plasma therapy in Asia was significantly higher than that in the United States and Europe. ${ }^{100}$ The reason for the 
high application of antibiotics in Asia may be related to the local diagnosis and treatment guidelines. ${ }^{101}$ In addition, doctors may be worried about the co-infection of bacteria and fungi, as well as potential iatrogenic infection, and it is difficult to distinguish viral from bacterial infection in a short time. ${ }^{102}$ According to their results, ${ }^{100}$ the application of antibiotics in the United States and Europe was also very common. In a report from the United States, more than $96 \%$ of patients with COVID-19 had no bacterial infection, so antibiotics might be unnecessary. ${ }^{103}$ Some reports have also shown that antiviral therapy has no obvious benefits. ${ }^{104,105}$ For moderate-risk and severe patients with COVID-19, oxygen sustain may increase ICU occupancy and the incidence of preterm birth. ${ }^{100}$ Immunosuppressants may cause serious adverse consequences, thus, the condition needs to be carefully evaluated before its application. ${ }^{106}$

\section{Polycystic Ovary Syndrome (PCOS) and COVID-I 9}

PCOS refers to the symptoms and signs of androgen overmuch and ovulation disorder after excluding other causes. $^{107}$ The mechanism of COVID-19 aggravation caused by androgen excess may be related to transmembrane protease serine 2 (TMPRSS2), which is a receptor required for COVID-19 infection. ${ }^{108}$ Besides, androgens may promote infection through immune regulation. ${ }^{109}$ Compared with normal women, PCOS patients have a $28 \%$ increased risk of COVID-19 infection. ${ }^{110}$ Furtherover, the symptoms of PCOS patients after infection were more obvious compared with infected women with normal androgen. ${ }^{111}$ These results suggest that doctors should strengthen the monitoring of women with PCOS during the epidemic. In addition to obesity, PCOS patients often have low-level inflammation, decreased vitamin $\mathrm{D}$ and imbalance of intestinal flora. ${ }^{112}$ These factors are the reasons why PCOS patients are prone to severe types of COVID-19 infection. ${ }^{113}$ The animal experiment suggested that infected mice with PCOS had cardiac, renal and gastrointestinal abnormalities. ${ }^{114}$ Therefore, physicians should pay attention to the changes of these organ functions in order to avoid these patients turning into severe cases. Metformin could be used to treat COVID19 , since it can change the ACE-2 receptor through activated protein kinase (AMPK) pathway, then, the virus can not enter the host. ${ }^{115}$ It should be noted that metformin may cause lactic acid accumulation in patients with dehydration or renal dysfunction among PCOS patients with COVID-19. ${ }^{116}$

\section{Pregnant Patients with Underlying Comorbidities}

A meta-analysis showed that pregnant women were more likely to develop into the severe cases if they were older than 35 years old, with hypertension, diabetes or body mass index (BMI) greater than $30 .^{39}$ Gestational diabetes mellitus and obesity are the most common comorbidities, and the mortality of these patients was increased by three times compared with normal pregnancies. ${ }^{117}$ Obese pregnant females with COVID-19 may have thrombotic diseases, therefore, anticoagulant therapy can be considered for this population. ${ }^{118}$ For infected pregnant women with comorbidities, they should be admitted to the specific hospital in time, with closely monitor for both mothers and fetuses, and multidisciplinary consultation and treatments were extremely essential. ${ }^{119}$ Moreover, more information about patients needs to be collected in order to identify pregnant women who may turn into severe types.

\section{Vertical Transmission and Breastfeeding for Pregnant Women with COVID-I 9}

According to the existed reports from China, the virus has not been found in the vaginal mucosa, umbilical cord blood, amniotic fluid, or throat swabs of newborns (Table 2). ${ }^{31}$ Pathological reports showed that there were no infectious or inflammatory changes in the placentas from pregnant patients with COVID-19 in some studies. ${ }^{120}$ One neonate developed COVID-19 infection 36 hours after delivery. ${ }^{121}$ Nevertheless, the results of the nucleic acid examination in umbilical cord blood and placenta were both negative for COVID-19, so vertical infection was not confirmed. ${ }^{121}$ Two newborns were born with positive PCR results through nasopharyngeal swabs, but there was no evidence of positive culture in the placenta or other tissues, so they were considered as possible cases. $^{122,123}$ PCR positive results have been found in amniotic fluid $^{124}$ and umbilical cord blood ${ }^{125}$ before rupture of fetal membranes during cesarean section in case reports. In other studies, viral specific $\operatorname{IgM}^{126}$ and $\operatorname{IgG}$ antibodies ${ }^{127}$ have been found to be elevated in blood of neonates after birth. However, all the throat swabs and blood samples showed negative RT-PCR results. In subsequent literature, the scholars did not consider the 
Table 2 Included Studies About Vertical Transmission

\begin{tabular}{|c|c|c|c|c|c|c|c|c|c|}
\hline Studies & $\begin{array}{l}\text { Number } \\
\text { of Tested } \\
\text { Neonates }\end{array}$ & $\begin{array}{l}\text { Neonatal } \\
\text { Throat } \\
\text { Swab Viral } \\
\text { RNA }\end{array}$ & $\begin{array}{l}\text { Cord } \\
\text { Blood } \\
\text { Viral } \\
\text { RNA }\end{array}$ & $\begin{array}{l}\text { Amniotic } \\
\text { Fluid } \\
\text { Viral } \\
\text { RNA }\end{array}$ & $\begin{array}{l}\text { Placenta } \\
\text { Viral } \\
\text { RNA }\end{array}$ & $\begin{array}{l}\text { Breast } \\
\text { Milk } \\
\text { Viral } \\
\text { RNA }\end{array}$ & $\begin{array}{l}\text { Increased } \\
\operatorname{IgM}(\geq 10 \\
\mathrm{AU} / \mathrm{mL})\end{array}$ & $\begin{array}{l}\text { Increased } \\
\text { IgG ( } \geq 10 \\
\text { AU/mL) }\end{array}$ & $\begin{array}{l}\text { Neonatal } \\
\text { Blood } \\
\text { Viral } \\
\text { RNA }\end{array}$ \\
\hline Chen et $\mathrm{al}^{3 \mathrm{I}}$ & 6 & - & - & - & NA & - & NA & NA & NA \\
\hline Yu et $\mathrm{al}^{121}$ & 3 & + & - & NA & - & NA & NA & NA & NA \\
\hline Kirtsman et al $^{122}$ & I & + & NA & NA & NA & NA & NA & NA & + \\
\hline Alzamora et al $^{123}$ & I & + & NA & NA & NA & NA & - & - & - \\
\hline Zamaniyan et al ${ }^{124}$ & I & + & - & + & NA & NA & NA & NA & NA \\
\hline Fenizia et al $^{125}$ & 31 & + & + & NA & + & + & NA & NA & NA \\
\hline Dong et $\mathrm{al}^{126}$ & I & - & NA & NA & NA & NA & + & + & NA \\
\hline Zeng et $\mathrm{al}^{127}$ & 6 & - & NA & NA & NA & NA & + & + & - \\
\hline Hosier et al ${ }^{129}$ & I & NA & + & NA & + & NA & NA & NA & NA \\
\hline Baud et al ${ }^{130}$ & I & - & - & - & + & NA & NA & NA & - \\
\hline Penfield et $\mathrm{al}^{|3|}$ & 11 & - & NA & NA & + & NA & NA & NA & NA \\
\hline Hecht et $\mathrm{al}^{132}$ & 19 & NA & NA & NA & + & NA & NA & NA & NA \\
\hline Menter et al ${ }^{133}$ & 5 & - & - & - & + & - & NA & NA & NA \\
\hline Vivanti et $a^{138}$ & I & + & NA & + & + & NA & NA & NA & + \\
\hline
\end{tabular}

Abbreviation: NA, non-analysed.

presence of $\operatorname{IgM}$ to be any evidence of vertical infection, since there are many technical issues in the detection of IgM antibody. ${ }^{128}$

Two cases were reported at 19 and 22 weeks of pregnancy, COVID-19 viruses were detected in both placentas, and the two fetuses died. ${ }^{129,130}$ These cases demonstrated the placental invasion of COVID-19, highlighting the seriousness of this virus among pregnant women. The possibility of virus contamination during delivery, sampling, or testing was low because samples from other tissues were all negative. No other cause of fetal death was found. In human placental tissues, the COVID-19 virus has been found by other detection methods, including $\mathrm{PCR},{ }^{131}$ positive strand RNA in situ hybridization, ${ }^{132,133}$ immunohistochemistry, ${ }^{134}$ and electron microscopy. ${ }^{135}$ In a systematic review involving 38 studies and 936 subjects, the authors analyzed the infection situation of newborns with positive COVID-19 mothers within 48 hours after birth, and they found that the rate of vertical transmission was $3.2 \%$ (95\% CI $2.2-4.3 \%) .{ }^{78}$ Up to now, the negative sense RNA representing virus replication has not been detected. The mechanism by which the virus enters the placental tissue is unclear, which may be related to placental inflammation. Further research is needed to determine whether the virus can pass through the placenta barrier.

We should be aware of the impact of viral load on the vertical transmission. Some assays have shown that more viral load of some viruses improves the possibility of vertical transmission; ${ }^{136,137}$ however, it is not clear whether SARS-CoV-2 has the same features. A study has shown that the incidence of vertical infection was related to the severity of the maternal condition. ${ }^{131}$ In a recent article from Alexandre et al, ${ }^{138}$ they confirmed a case of transplacental transmission of COVID-19 infection in late pregnancy with neonatal nervous system abnormalities, which may be related to the high viral load in the placenta.

Based on the common view of Chinese experts, if the mother of the newborn is suspected or diagnosed with COVID-19, the infants should be isolated for two weeks. Our hospital is not a designated delivery center for suspected or confirmed COVID-19 patients; however, since it is a tertiary hospital, we have developed a workflow for emergency admission of pregnant women during the epidemic of COVID-19 pneumonia (Figure 1). One study found the SARS-CoV-2 virus in breast milk, ${ }^{139}$ however, most of the other studies did not find the virus in breast milk, ${ }^{31}$ so breastfeeding is not forbidden for suspected or confirmed patients with COVID-19.

ACE2 is a receptor of SARS-CoV-2 for human beings. The relationship between ACE2 and SARS-CoV-2 at the maternal-fetal interface is controversial. Dong et $\mathrm{al}^{126}$ found a temporary up-regulation and elevated response of ACE2 in the placenta and generative organs of pregnant rats. However, Zeng et $\mathrm{al}^{127}$ found that the expression of ACE2 was very low at the maternal fetal interface in the 


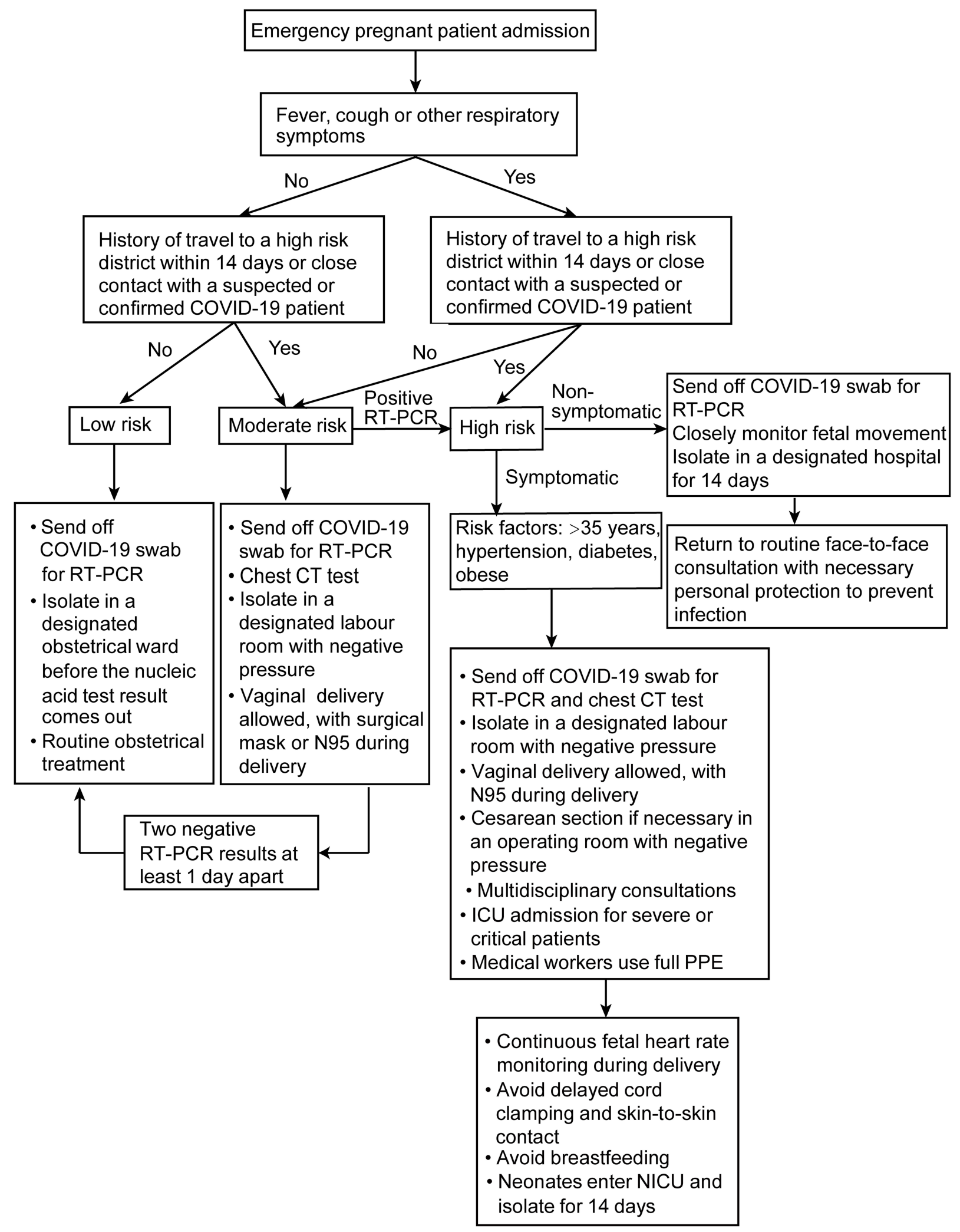

Figure I Admission workflow of emergency pregnant patients during the epidemic of COVID-19 pneumonia in our hospital.

Abbreviations: COVID-19, novel coronavirus disease; RT-PCR, Reverse Transcription-Polymerase Chain Reaction; CT, Computed Tomography; ICU, intensive care unit; PPE, personal protective equipment; NICU, neonatal intensive care unit. 
first trimester, indicating that the placenta was not susceptible to SARS-CoV-2. This may be explained by the absence of TMPRSS2 in the placenta. The role of TMPRSS2 is to assist the SARS-CoV-2 virus in entering cells, but this is just a hypothesis. ${ }^{108,128}$ The possible mechanism of vertical transmission of SARS-CoV-2 in pregnant women is shown in Figure 2. Besides, COVID19 may have some other receptors in the placenta that need further study, including CD147, NRP1, and Cathepsine L-like cysteine protease proteases (CTLS). ${ }^{140-142}$ Regarding the studies that were included in this review, there is a possibility of underestimating the problem. On the contrary, the type of publications may increase the real vulnerability of pregnant women and mothers to infection and to the disease as a consequence of the tendency to publish severe cases.

\section{Conclusions}

In a word, pregnant women infected with COVID-19 may develop into severe respiratory distress and perinatal death. Compared with non-pregnant females, pregnant women may have a higher probability of ICU admission and endotracheal intubation. The long-term prognosis is still uncertain and requires investigations in detail. Vaccines can significantly reduce the incidence of severe diseases. At present, there is no report of obvious side effects of vaccines. Therefore, pregnant and lactating women should be suggested to receive vaccination. All factors should be inspected for the benefit/risk assessment. Steroids, zinc/magnesium and plasma treatment have been employed among pregnant women with COVID-19. ${ }^{100}$ By reducing unnecessary treatments, such as antibiotics and immunosuppressive drugs, risk stratification and detailed evaluation can promote the prognosis of mothers and infants. Symptomatic patients should be treated differently than non-symptomatic patients since the former may progress to the severe type of COVID19. Pregnant women with related comorbidities should be given priority to the measurement of vaccinal effectiveness and security. Weight and specific comorbidities can

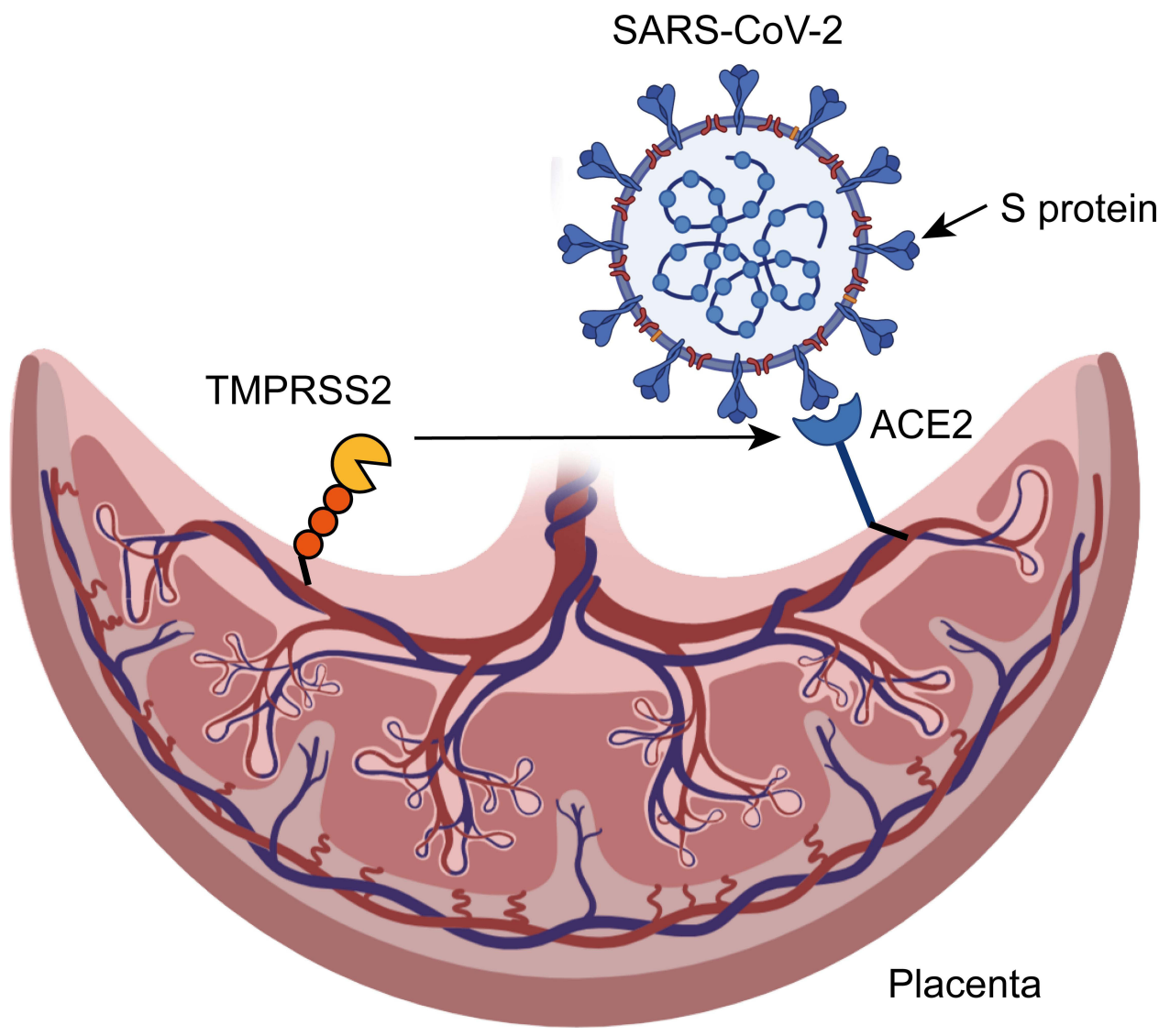

Figure 2 The possible mechanism of vertical transmission of SARS-CoV-2 in pregnant women.

Notes: In infection process, SARS-CoV-2 combines with angiotensin-converting enzyme 2 (ACE2) through sharp $S$ protein on the surface of the virus. Afterwards, transmembrane protease serine 2 (TMPRSS2) helps the S protein of SARS-CoV- 2 to enter the cell and cause infection. 
be controlled before pregnancy to reduce the risk of infection in pregnancy. Pregnant women with hypertension, diabetes, obesity, and ethnic minorities should be hospitalized in time regardless of illness seriousness. As the pneumonia progresses day by day, obstetricians should be aware of the characteristics of this pneumonia in pregnant women, strengthen routine monitoring of COVID-19, identify asymptomatic pregnant women as early as possible, and properly treat pregnant women infected with COVID-19, to avoid adverse pregnancy outcomes.

\section{Funding}

There is no funding to report.

\section{Disclosure}

The authors report no conflicts of interest in this work.

\section{References}

1. Lu R, Zhao X, Li J, et al. Genomic characterisation and epidemiology of 2019 novel coronavirus: implications for virus origins and receptor binding. Lancet. 2020;395(10224):565-574. doi:10. 1016/S0140-6736(20)30251-8

2. $\mathrm{Xu} \mathrm{X}$, Chen $\mathrm{P}$, Wang J, et al. Evolution of the novel coronavirus from the ongoing Wuhan outbreak and modeling of its spike protein for risk of human transmission. Sci China Life Sci. 2020;63(3):457-460. doi:10.1007/s11427-020-1637-5

3. Somerset DA, Zheng Y, Kilby MD, Sansom DM, Drayson MT. Normal human pregnancy is associated with an elevation in the immune suppressive CD25+ CD4+ regulatory T-cell subset. Immunology. 2004;112(1):38-43. doi:10.1111/j.1365-2567.2004. 01869.x

4. Chan JF, Yuan S, Kok KH, et al. A familial cluster of pneumonia associated with the 2019 novel coronavirus indicating person-toperson transmission: a study of a family cluster. Lancet. 2020;395 (10223):514-523. doi:10.1016/S0140-6736(20)30154-9

5. Wu Z, McGoogan JM. Characteristics of and Important Lessons From the Coronavirus Disease 2019 (COVID-19) Outbreak in China: summary of a Report of 72314 Cases From the Chinese Center for Disease Control and Prevention. JAMA. 2020;323 (13):1239. doi:10.1001/jama.2020.2648

6. Veglia M, D'Ippolito S, Marana R, et al. Human IgG Antinuclear Antibodies Induce Pregnancy Loss in Mice by Increasing Immune Complex Deposition in Placental Tissue: in Vivo Study. Am J Reprod Immunol. 2015;74(6):542-552. doi:10.1111/ aji.12429

7. O'Day MP. Cardio-respiratory physiological adaptation of pregnancy. Semin Perinatol. 1997;21(4):268-275. doi:10.1016/ S0146-0005(97)80069-9

8. Weetman AP. Immunity, thyroid function and pregnancy: molecular mechanisms. Nat Rev Endocrinol. 2010;6(6):311-318. doi:10.1038/nrendo.2010.46

9. Longman RE, Johnson TR. Viral respiratory disease in pregnancy. Curr Opin Obstet Gynecol. 2007;19(2):120-125. doi:10.1097/ GCO.0b013e328028fdc7

10. Pazos M, Sperling RS, Moran TM, Kraus TA. The influence of pregnancy on systemic immunity. Immunol Res. 2012;54(13):254-261. doi:10.1007/s12026-012-8303-9
11. Picone O, Bouthry E, Bejaoui-Olhmann Y, et al. Determination of rubella virus-specific humoral and cell-mediated immunity in pregnant women with negative or equivocal rubella-specific IgG in routine screening. J Clin Virol. 2019;112:27-33. doi:10.1016/j. jcv.2019.01.009

12. Tsafaras GP, Ntontsi P, Xanthou G. Advantages and Limitations of the Neonatal Immune System. Front Pediatr. 2020;8:5. doi:10.3389/fped.2020.00005

13. Muyayalo KP, Huang DH, Zhao SJ, Xie T, Mor G, Liao AH. COVID-19 and Treg/Th17 imbalance: potential relationship to pregnancy outcomes. Am J Reprod Immunol. 2020;84(5):e133 04. doi:10.1111/aji.13304

14. Xu Z, Shi L, Wang Y, et al. Pathological findings of COVID-19 associated with acute respiratory distress syndrome. Lancet Respir Med. 2020;8(4):420-422. doi:10.1016/S2213-2600(20)30076-X

15. Figueiredo AS, Schumacher A. The T helper type 17/regulatory $\mathrm{T}$ cell paradigm in pregnancy. Immunology. 2016;148(1):13-21. doi:10.1111/imm.12595

16. Jørgensen N, Persson G, Hviid TVF. The Tolerogenic Function of Regulatory T Cells in Pregnancy and Cancer. Front Immunol. 2019;10:911. doi:10.3389/fimmu.2019.00911

17. Lee SK, Kim JY, Lee M, Gilman-Sachs A, Kwak-Kim J. Th17 and regulatory $\mathrm{T}$ cells in women with recurrent pregnancy loss. Am J Reprod Immunol. 2012;67(4):311-318. doi:10.1111/j.16000897.2012.01116.x

18. Jabalie G, Ahmadi M, Koushaeian L, et al. Metabolic syndrome mediates proinflammatory responses of inflammatory cells in preeclampsia. Am J Reprod Immunol. 2019;81(3):e13086. doi:10. 1111/aji.13086

19. Kwak-Kim J, Ota K, Sung N, et al. COVID-19 and immunomodulation treatment for women with reproductive failures. $J$ Reprod Immunol. 2020;141:103168. doi:10.1016/j.jri.2020.103168

20. Wong SF, Chow KM, Leung TN, et al. Pregnancy and perinatal outcomes of women with severe acute respiratory syndrome. Am JObstet Gynecol. 2004;191(1):292-297. doi:10.1016/j.ajog.2003.11.019

21. Schwartz DA, Graham AL. Potential Maternal and Infant Outcomes from (Wuhan) Coronavirus 2019-nCoV Infecting Pregnant Women: lessons from SARS, MERS, and Other Human Coronavirus Infections. Viruses. 2020;12(2):25. doi:10. 3390/v12020194

22. Lam CM, Wong SF, Leung TN, et al. A case-controlled study comparing clinical course and outcomes of pregnant and non-pregnant women with severe acute respiratory syndrome. Bjog. 2004;111 (8):771-774. doi:10.1111/j.1471-0528.2004.00199.x

23. Maxwell C, McGeer A, Tai KFY, Sermer M. No. 225-Management Guidelines for Obstetric Patients and Neonates Born to Mothers With Suspected or Probable Severe Acute Respiratory Syndrome (SARS). J Obstet Gynaecol Can. 2017;39(8):e130-e137. doi:10.1016/j.jogc.2017.04.024

24. Shek CC, Ng PC, Fung GP, et al. Infants born to mothers with severe acute respiratory syndrome. Pediatrics. 2003;112(4):e254. doi:10.1542/peds.112.4.e254

25. Ng PC, Leung CW, Chiu WK, Wong SF, Hon EK. SARS in newborns and children. Biol Neonate. 2004;85(4):293-298. doi:10.1159/000078174

26. Li AM, Ng PC. Severe acute respiratory syndrome (SARS) in neonates and children. Arch Dis Child Fetal Neonatal Ed. 2005;90(6):F461-5. doi:10.1136/adc.2005.075309

27. Arabi YM, Balkhy HH, Hayden FG, et al. Middle East Respiratory Syndrome. N Engl J Med. 2017;376(6):584-594. doi:10.1056/NEJMsr1408795

28. Alfaraj SH, Al-Tawfiq JA, Memish ZA. Middle East Respiratory Syndrome Coronavirus (MERS-CoV) infection during pregnancy: report of two cases \& review of the literature. J Microbiol Immunol Infect. 2019;52(3):501-503. doi:10.1016/j.jmii.2018. 04.005 
29. Payne DC, Iblan I, Alqasrawi S, et al. Stillbirth during infection with Middle East respiratory syndrome coronavirus. J Infect Dis. 2014;209(12):1870-1872. doi:10.1093/infdis/jiu068

30. Jeong SY, Sung SI, Sung JH, et al. MERS-CoV Infection in a Pregnant Woman in Korea. J Korean Med Sci. 2017;32 (10):1717-1720. doi:10.3346/jkms.2017.32.10.1717

31. Chen H, Guo J, Wang C, et al. Clinical characteristics and intrauterine vertical transmission potential of COVID-19 infection in nine pregnant women: a retrospective review of medical records. Lancet. 2020;395(10226):809-815. doi:10.1016/S01406736(20)30360-3

32. Wen R, Sun Y, Xing QS. A patient with SARS-CoV-2 infection during pregnancy in Qingdao, China. J Microbiol Immunol Infect. 2020;53(3):499-500. doi:10.1016/j.jmii.2020.03.004

33. Liu H, Liu F, Li J, Zhang T, Wang D, Lan W. Clinical and CT imaging features of the COVID-19 pneumonia: focus on pregnant women and children. $J$ Infect. 2020;80(5):e7-e13. doi:10.1016/j. jinf.2020.03.007

34. Elshafeey F, Magdi R, Hindi N, et al. A systematic scoping review of COVID-19 during pregnancy and childbirth. Int J Gynaecol Obstet. 2020;150(1):47-52. doi:10.1002/ijgo.13182

35. Mor G, Cardenas I. The immune system in pregnancy: a unique complexity. Am J Reprod Immunol. 2010;63(6):425-433. doi:10. 1111/j.1600-0897.2010.00836.x

36. Kayem G, Lecarpentier E, Deruelle P, et al. A snapshot of the Covid-19 pandemic among pregnant women in France. J Gynecol Obstet Hum Reprod. 2020;49(7):101826. doi:10.1016/j.jogoh.20 20.101826

37. Vousden N, Bunch K, Morris E, et al. The incidence, characteristics and outcomes of pregnant women hospitalized with symptomatic and asymptomatic SARS-CoV-2 infection in the UK from March to September 2020: a national cohort study using the UK Obstetric Surveillance System (UKOSS). PLoS One. 2021;16(5): e0251123. doi:10.1371/journal.pone.0251123

38. Mullins E, Hudak ML, Banerjee J, et al. Pregnancy and neonatal outcomes of COVID-19: coreporting of common outcomes from PAN-COVID and AAP-SONPM registries. Ultrasound Obstet Gynecol. 2021;57(4):573-581. doi:10.1002/uog.23619

39. Allotey J, Stallings E, Bonet M, et al. Clinical manifestations, risk factors, and maternal and perinatal outcomes of coronavirus disease 2019 in pregnancy: living systematic review and meta-analysis. BMJ. 2020;370:m3320. doi:10.1136/bmj.m3320

40. Di Toro F, Gjoka M, Di Lorenzo G, et al. Impact of COVID-19 on maternal and neonatal outcomes: a systematic review and meta-analysis. Clin Microbiol Infect. 2021;27(1):36-46. doi:10. 1016/j.cmi.2020.10.007

41. Huntley BJF, Huntley ES, Di Mascio D, Chen T, Berghella V, Chauhan SP. Rates of Maternal and Perinatal Mortality and Vertical Transmission in Pregnancies Complicated by Severe Acute Respiratory Syndrome Coronavirus 2 (SARS-Co-V-2) Infection: a Systematic Review. Obstet Gynecol. 2020;136 (2):303-312. doi:10.1097/AOG.0000000000004010

42. Juan J, Gil MM, Rong Z, Zhang Y, Yang H, Poon LC. Effect of coronavirus disease 2019 (COVID-19) on maternal, perinatal and neonatal outcome: systematic review. Ultrasound Obstet Gynecol. 2020;56(1):15-27. doi:10.1002/uog.22088

43. Knight M, Bunch K, Vousden N, et al. Characteristics and outcomes of pregnant women admitted to hospital with confirmed SARS-CoV-2 infection in UK: national population based cohort study. BMJ. 2020;369:m2107. doi:10.1136/bmj.m2107

44. Guan WJ, Liang WH, Zhao Y, et al. Comorbidity and its impact on 1590 patients with COVID-19 in China: a nationwide analysis. Eur Respir J. 2020;55(5):478. doi:10.1183/13993003.00547-2020

45. Guan WJ, Ni ZY, Hu Y, et al. Clinical Characteristics of Coronavirus Disease 2019 in China. N Engl J Med. 2020;382 (18):1708-1720. doi:10.1056/NEJMoa2002032
46. Richardson S, Hirsch JS, Narasimhan M, et al. Presenting Characteristics, Comorbidities, and Outcomes Among 5700 Patients Hospitalized With COVID-19 in the New York City Area. JAMA. 2020;323(20):2052-2059. doi:10.1001/jama.2020. 6775

47. Mendoza M, Garcia-Ruiz I, Maiz N, et al. Pre-eclampsia-like syndrome induced by severe COVID-19: a prospective observational study. Bjog. 2020;127(11):1374-1380. doi:10.1111/14710528.16339

48. Rolnik DL. Can COVID-19 in pregnancy cause pre-eclampsia? Bjog. 2020;127(11):1381. doi:10.1111/1471-0528.16369

49. Smithgall MC, Liu-Jarin X, Hamele-Bena D, et al. Third-trimester placentas of severe acute respiratory syndrome coronavirus 2 (SARS-CoV-2)-positive women: histomorphology, including viral immunohistochemistry and in-situ hybridization. Histopathology. 2020;77(6):994-999. doi:10.1111/his.14215

50. Benhamou D, Keita H, Ducloy-Bouthors AS. Coagulation changes and thromboembolic risk in COVID-19 obstetric patients. Anaesth Crit Care Pain Med. 2020;39(3):351-353. doi:10.1016/j.accpm.2020.05.003

51. Dennis CL, Ross LE, Herxheimer A. Oestrogens and progestins for preventing and treating postpartum depression. Cochrane Database Syst Rev. 2008;2008(4):Cd001690.

52. Kraus TA, Engel SM, Sperling RS, et al. Characterizing the pregnancy immune phenotype: results of the viral immunity and pregnancy (VIP) study. J Clin Immunol. 2012;32(2):300-311. doi:10.1007/s10875-011-9627-2

53. Ellington S, Strid P, Tong VT, et al. Characteristics of Women of Reproductive Age with Laboratory-Confirmed SARS-CoV-2 Infection by Pregnancy Status - United States, January 22-June 7, 2020. MMWR Morb Mortal Wkly Rep. 2020;69 (25):769-775. doi:10.15585/mmwr.mm6925a1

54. Collin J, Byström E, Carnahan A, Ahrne M. Public Health Agency of Sweden's Brief Report: pregnant and postpartum women with severe acute respiratory syndrome coronavirus 2 infection in intensive care in Sweden. Acta Obstet Gynecol Scand. 2020;99(7):819-822. doi:10.1111/aogs.13901

55. Delahoy MJ, Whitaker M, O'Halloran A, et al. Characteristics and Maternal and Birth Outcomes of Hospitalized Pregnant Women with Laboratory-Confirmed COVID-19 COVID-NET, 13 States, March 1-August 22, 2020. MMWR Morb Mortal Wkly Rep. 2020;69(38):1347-1354. doi:10.15 585/mmwr.mm6938e1

56. Panagiotakopoulos L, Myers TR, Gee J, et al. SARS-CoV-2 Infection Among Hospitalized Pregnant Women: reasons for Admission and Pregnancy Characteristics - Eight U.S. Health Care Centers, March 1-May 30, 2020. MMWR Morb Mortal Wkly Rep. 2020;69(38):1355-1359. doi:10.15585/mmwr.mm69 $38 \mathrm{e} 2$

57. Lebel C, MacKinnon A, Bagshawe M, Tomfohr-Madsen L, Giesbrecht G. Elevated depression and anxiety symptoms among pregnant individuals during the COVID-19 pandemic. J Affect Disord. 2020;277:5-13. doi:10.1016/j.jad.2020.07.126

58. Wang C, Pan R, Wan X, et al. Immediate Psychological Responses and Associated Factors during the Initial Stage of the 2019 Coronavirus Disease (COVID-19) Epidemic among the General Population in China. Int J Environ Res Public Health. 2020;17(5):658.

59. Wang J, Zhou Y, Qian W, Zhou Y, Han R, Liu Z. Maternal insomnia during the COVID-19 pandemic: associations with depression and anxiety. Soc Psychiatry Psychiatr Epidemiol. 2021;56(8):1477-1485. doi:10.1007/s00127-021-02072-2

60. Glover V, Bergman K, Sarkar P, O’Connor TG. Association between maternal and amniotic fluid cortisol is moderated by maternal anxiety. Psychoneuroendocrinology. 2009;34(3):430-4 35. doi:10.1016/j.psyneuen.2008.10.005 
61. Bayrampour H, Tomfohr L, Tough S. Trajectories of Perinatal Depressive and Anxiety Symptoms in a Community Cohort. J Clin Psychiatry. 2016;77(11):e1467-e1473. doi:10.4088/JCP.15m10176

62. Qu F, Wu Y, Zhu YH, et al. The association between psychological stress and miscarriage: a systematic review and meta-analysis. Sci Rep. 2017;7(1):1731. doi:10.1038/s41598-017-01792-3

63. Stein A, Pearson RM, Goodman SH, et al. Effects of perinatal mental disorders on the fetus and child. Lancet. 2014;384 (9956):1800-1819. doi:10.1016/S0140-6736(14)61277-0

64. Adamson B, Letourneau N, Lebel C. Prenatal maternal anxiety and children's brain structure and function: a systematic review of neuroimaging studies. $J$ Affect Disord. 2018;241:117-126. doi:10.1016/j.jad.2018.08.029

65. MacKinnon N, Kingsbury M, Mahedy L, Evans J, Colman I. The Association Between Prenatal Stress and Externalizing Symptoms in Childhood: evidence From the Avon Longitudinal Study of Parents and Children. Biol Psychiatry. 2018;83(2):100-108. doi:10.1016/j.biopsych.2017.07.010

66. Chen L, Li Q, Zheng D, et al. Clinical Characteristics of Pregnant Women with Covid-19 in Wuhan, China. N Engl J Med. 2020;382 (25):e100. doi:10.1056/NEJMc2009226

67. $\mathrm{Xu} \mathrm{L}$, Yang Q, Shi H, et al. Clinical presentations and outcomes of SARS-CoV-2 infected pneumonia in pregnant women and health status of their neonates. Sci Bull. 2020;65(18):15 37-1542. doi:10.1016/j.scib.2020.04.040

68. Birkeland SA, Kristoffersen K. T and B lymphocytes during normal human pregnancy: a longitudinal study. Scand J Immunol. 1979;10(5):415-419. doi:10.1111/j.1365-3083.1979. tb01370.x

69. Khoury P, Stokes K, Gadkari M, et al. Glucocorticoid-induced eosinopenia in humans can be linked to early transcriptional events. Allergy. 2018;73(10):2076-2079. doi:10.1111/all.13497

70. Ai T, Yang Z, Hou H, et al. Correlation of Chest CT and RT-PCR Testing in Coronavirus Disease 2019 (COVID-19) in China: a Report of 1014 Cases. Radiology. 2020;2:200642.

71. Dotters-Katz SK, Hughes BL. Considerations for Obstetric Care during the COVID-19 Pandemic. Am J Perinatol. 2020;2:58.

72. Huang C, Wang Y, Li X, et al. Clinical features of patients infected with 2019 novel coronavirus in Wuhan, China. Lancet. 2020;395(10223):497-506. doi:10.1016/S0140-6736(20)30183-5

73. Zhang L, Jiang Y, Wei M, et al. [Analysis of the pregnancy outcomes in pregnant women with COVID-19 in Hubei Province]. Zhonghua Fu Chan Ke Za Zhi. 2020;55(3):166-171. Chinese.

74. Di Mascio D, Khalil A, Saccone G, et al. Outcome of Coronavirus spectrum infections (SARS, MERS, COVID 1-19) during pregnancy: a systematic review and meta-analysis. $\mathrm{Am}$ J Obstet Gynecol MFM. 2020;2(2):100107. doi:10.1016/j.ajogmf. 2020.100107

75. Poon LC, Yang H, Lee JCS, et al. ISUOG Interim Guidance on 2019 novel coronavirus infection during pregnancy and puerperium: information for healthcare professionals. Ultrasound Obstet Gynecol. 2020;55(5):700-708. doi:10.1002/uog.22013

76. Kovac M, Mikovic Z, Rakicevic L, et al. The use of D-dimer with new cutoff can be useful in diagnosis of venous thromboembolism in pregnancy. Eur J Obstet Gynecol Reprod Biol. 2010;148 (1):27-30. doi:10.1016/j.ejogrb.2009.09.005

77. Dubey P, Reddy SY, Manuel S, Dwivedi AK. Maternal and neonatal characteristics and outcomes among COVID-19 infected women: an updated systematic review and meta-analysis. Eur J Obstet Gynecol Reprod Biol. 2020;252:490-501. doi:10.1016/ j.ejogrb.2020.07.034

78. Kotlyar AM, Grechukhina O, Chen A, et al. Vertical transmission of coronavirus disease 2019: a systematic review and meta-analysis. Am J Obstet Gynecol. 2021;224(1):35-53.e3. doi:10.1016/j.ajog.2020.07.049
79. Yuki K, Fujiogi M, Koutsogiannaki S. COVID-19 pathophysiology: a review. Clin Immunol. 2020;215:108427. doi:10.1016/j. clim.2020.108427

80. Yan J, Guo J, Fan C, et al. Coronavirus disease 2019 in pregnant women: a report based on 116 cases. Am J Obstet Gynecol. 2020;223(1):111.e1-111.e14. doi:10.1016/j.ajog.2020.04.014

81. Yoon SH, Kang JM, Ahn JG. Clinical outcomes of 201 neonates born to mothers with COVID-19: a systematic review. Eur Rev Med Pharmacol Sci. 2020;24(14):7804-7815.

82. Aassve A, Cavalli N, Mencarini L, Plach S, Livi Bacci M. The COVID-19 pandemic and human fertility. Science. 2020;369 (6502):370-371.

83. Dashraath P, Wong JLJ, Lim MXK, et al. Coronavirus disease 2019 (COVID-19) pandemic and pregnancy. Am J Obstet Gynecol. 2020;222(6):521-531. doi:10.1016/j.ajog.2020.03.021

84. Moore SA, Dietl CA, Coleman DM. Extracorporeal life support during pregnancy. $J$ Thorac Cardiovasc Surg. 2016;151 (4):1154-1160. doi:10.1016/j.jtcvs.2015.12.027

85. Zheng -Y-Y, Ma Y-T, Zhang J-Y, Xie X. COVID-19 and the cardiovascular system. Nat Rev Cardiol. 2020;17(5):259-260. doi:10.1038/s41569-020-0360-5

86. Zhou F, Yu T, Du R, et al. Clinical course and risk factors for mortality of adult inpatients with COVID-19 in Wuhan, China: a retrospective cohort study. Lancet. 2020;395(10229):10 54-1062.

87. Favre G, Pomar L, Qi X, Nielsen-Saines K, Musso D, Baud D. Guidelines for pregnant women with suspected SARS-CoV-2 infection. Lancet Infect Dis. 2020;20(6):652-653. doi:10.1016/ S1473-3099(20)30157-2

88. Alserehi H, Wali G, Alshukairi A, Alraddadi B. Impact of Middle East Respiratory Syndrome coronavirus (MERS-CoV) on pregnancy and perinatal outcome. BMC Infect Dis. 2016;16:105. doi:10.1186/s12879-016-1437-y

89. Wang M, Cao R, Zhang L, et al. Remdesivir and chloroquine effectively inhibit the recently emerged novel coronavirus (2019-nCoV) in vitro. Cell Res. 2020;30(3):269-271. doi:10. 1038/s41422-020-0282-0

90. Vogel JP, Tendal B, Giles M, et al. Clinical care of pregnant and postpartum women with COVID-19: living recommendations from the National COVID-19 Clinical Evidence Taskforce. Aust N Z J Obstet Gynaecol. 2020;60(6):840-851. doi:10.1111/ajo. 13270

91. Karunajeewa HA, Salman S, Mueller I, et al. Pharmacokinetics of chloroquine and monodesethylchloroquine in pregnancy. Antimicrob Agents Chemother. 2010;54(3):1186-1192. doi:10.11 28/AAC.01269-09

92. Gao J, Tian Z, Yang X. Breakthrough: chloroquine phosphate has shown apparent efficacy in treatment of COVID-19 associated pneumonia in clinical studies. Biosci Trends. 2020;14(1):72-73. doi: $10.5582 /$ bst. 2020.01047

93. Rasmussen SA, Kelley CF, Horton JP, Jamieson DJ. Coronavirus Disease 2019 (COVID-19) Vaccines and Pregnancy: what Obstetricians Need to Know. Obstet Gynecol. 2021;137 (3):408-414. doi:10.1097/AOG.0000000000004290

94. Polack FP, Thomas SJ, Kitchin N, et al. Safety and Efficacy of the BNT162b2 mRNA Covid-19 Vaccine. $N$ Engl J Med. 2020;383 (27):2603-2615. doi:10.1056/NEJMoa2034577

95. Jackson LA, Anderson EJ, Rouphael NG, et al. An mRNA Vaccine against SARS-CoV-2 - Preliminary Report. N Engl J Med. 2020;383(20):1920-1931. doi:10.1056/NEJMoa2022483

96. McNeil MM, Gee J, Weintraub ES, et al. The Vaccine Safety Datalink: successes and challenges monitoring vaccine safety. Vaccine. 2014;32 (42):5390-5398. doi:10.1016/j.vaccine.2014.07.073

97. Wiwanitkit V. Safety of influenza A (H1N1) 2009 live attenuated monovalent vaccine in pregnant women. Obstet Gynecol. 2014;123(3):665-666. doi:10.1097/AOG.0000000000000153 
98. Craig AM, Hughes BL, Swamy GK. Coronavirus disease 2019 vaccines in pregnancy. Am J Obstet Gynecol MFM. 2021;3 (2):100295. doi:10.1016/j.ajogmf.2020.100295

99. Gray KJ, Bordt EA, Atyeo C, et al. COVID-19 vaccine response in pregnant and lactating women: a cohort study. medRxiv. 2021;1.

100. Dubey P, Thakur B, Reddy S, et al. Current trends and geographical differences in therapeutic profile and outcomes of COVID-19 among pregnant women - a systematic review and meta-analysis. BMC Pregnancy Childbirth. 2021;21(1):247. doi:10.1186/s12884-021-03685-w

101. Beović B, Doušak M, Ferreira-Coimbra J, et al. Antibiotic use in patients with COVID-19: a 'snapshot' Infectious Diseases International Research Initiative (ID-IRI) survey. $J$ Antimicrob Chemother. 2020;75(11):3386-3390. doi:10.1093/jac/dkaa326

102. Getahun H, Smith I, Trivedi K, Paulin S, Balkhy HH. Tackling antimicrobial resistance in the COVID-19 pandemic. Bull World Health Organ. 2020;98(7):442-442a. doi:10.2471/BLT. 20.268573

103. Vaughn VM, Gandhi TN, Petty LA, et al. Empiric Antibacterial Therapy and Community-onset Bacterial Coinfection in Patients Hospitalized With Coronavirus Disease 2019 (COVID-19): a Multi-hospital Cohort Study. Clin Infect Dis. 2021;72(10):e533e541. doi:10.1093/cid/ciaa1239

104. Beigel JH, Tomashek KM, Dodd LE, et al. Remdesivir for the Treatment of Covid-19 - Final Report. $N$ Engl J Med. 2020;383 (19):1813-1826. doi:10.1056/NEJMoa2007764

105. Nielsen Jeschke K, Bonnesen B, Hansen EF, et al. Guideline for the management of COVID-19 patients during hospital admission in a non-intensive care setting. Eur Clin Respir J. 2020;7 (1):1761677. doi:10.1080/20018525.2020.1761677

106. Thng ZX, De Smet MD, Lee CS, et al. COVID-19 and immunosuppression: a review of current clinical experiences and implications for ophthalmology patients taking immunosuppressive drugs. $B r J$ Ophthalmol. 2021;105(3):306-310. doi:10.1136/ bjophthalmol-2020-316586

107. De Leo V, Musacchio MC, Cappelli V, Massaro MG, Morgante G, Petraglia F. Genetic, hormonal and metabolic aspects of PCOS: an update. Reprod Biol Endocrinol. 2016;14 (1):38. doi:10.1186/s12958-016-0173-x

108. Hoffmann M, Kleine-Weber H, Schroeder S, et al. SARS-CoV-2 Cell Entry Depends on ACE2 and TMPRSS2 and Is Blocked by a Clinically Proven Protease Inhibitor. Cell. 2020;181(2):271280.e8. doi:10.1016/j.cell.2020.02.052

109. Sharifi N, Ryan CJ. Androgen hazards with COVID-19. Endocr Relat Cancer. 2020;27(6):E1-e3. doi:10.1530/ERC-20-0133

110. Subramanian A, Anand A, Adderley NJ, et al. Increased COVID-19 infections in women with polycystic ovary syndrome: a population-based study. Eur J Endocrinol. 2021;184 (5):637-645. doi:10.1530/EJE-20-1163

111. Cadegiani FA, Lim RK, Goren A, et al. Clinical symptoms of hyperandrogenic women diagnosed with COVID-19. J Eur Acad Dermatol Venereol. 2021;35(2):e101-e104. doi:10.1111/jdv. 17004

112. Ortolan A, Lorenzin M, Felicetti M, Doria A, Ramonda R. Does gender influence clinical expression and disease outcomes in COVID-19? A systematic review and meta-analysis. Int J Infect Dis. 2020;99:496-504. doi:10.1016/j.ijid.2020.07.076

113. Morgante G, Troìa L, De Leo V. Coronavirus Disease 2019 (SARS-CoV-2) and polycystic ovarian disease: is there a higher risk for these women? J Steroid Biochem Mol Biol. 2021;205:105770. doi:10.1016/j.jsbmb.2020.105770

114. Huffman AM, Rezq S, Basnet J, Yanes Cardozo LL, Romero DG. SARS-CoV-2 Viral Entry Proteins in Hyperandrogenemic Female Mice: implications for Women with PCOS and COVID-19. Int J Mol Sci. 2021;22(9):487. doi:10.3390/ijms22094472
115. Sharma S, Ray A, Sadasivam B. Metformin in COVID-19: a possible role beyond diabetes. Diabetes Res Clin Pract. 2020;164:108183. doi:10.1016/j.diabres.2020.108183

116. Bornstein SR, Rubino F, Khunti K, et al. Practical recommendations for the management of diabetes in patients with COVID-19. Lancet Diabetes Endocrinol. 2020;8(6):546-550. doi:10.1016/ S2213-8587(20)30152-2

117. Takemoto M, Menezes MO, Andreucci CB, et al. Clinical characteristics and risk factors for mortality in obstetric patients with severe COVID-19 in Brazil: a surveillance database analysis. Bjog. 2020;127(13):1618-1626. doi:10.1111/1471-0528.16470

118. Teixeira MLB. Maternal and Neonatal Outcomes of SARS-CoV-2 Infection in a Cohort of Pregnant Women with Comorbid Disorders. Viruses. 2021;13(7):69. doi:10.3390/v13071277

119. National Institutes of Health (US). Coronavirus Disease 2019 (COVID-19) Treatment Guidelines. National Institutes of Health (US); 2021.

120. Lamouroux A, Attie-Bitach T, Martinovic J, Leruez-Ville M, Ville Y. Evidence for and against vertical transmission for SARS-CoV-2 (COVID-19). Am J Obstet Gynecol. 2020;223 (1):91.e1-4. doi:10.1016/j.ajog.2020.04.039

121. Yu N, Li W, Kang Q, et al. Clinical features and obstetric and neonatal outcomes of pregnant patients with COVID-19 in Wuhan, China: a retrospective, single-centre, descriptive study. Lancet Infect Dis. 2020;20(5):559-564. doi:10.1016/S1473-3099(20)30176-6

122. Kirtsman M, Diambomba Y, Poutanen SM, et al. Probable congenital SARS-CoV-2 infection in a neonate born to a woman with active SARS-CoV-2 infection. Cmaj. 2020;192(24):E647-e650. doi:10.1503/cmaj.200821

123. Alzamora MC, Paredes T, Caceres D, Webb CM, Valdez LM, La Rosa M. Severe COVID-19 during Pregnancy and Possible Vertical Transmission. Am J Perinatol. 2020;37(8):861-865. doi:10.1055/s-0040-1710050

124. Zamaniyan M, Ebadi A, Aghajanpoor S, Rahmani Z, Haghshenas M, Azizi S. Preterm delivery, maternal death, and vertical transmission in a pregnant woman with COVID-19 infection. Prenat Diagn. 2020;40(13):1759-1761. doi:10.1002/pd.5713

125. Fenizia C, Biasin M, Cetin I, et al. Analysis of SARS-CoV-2 vertical transmission during pregnancy. Nat Commun. 2020;11 (1):5128. doi:10.1038/s41467-020-18933-4

126. Dong L, Tian J, He S, et al. Possible Vertical Transmission of SARS-CoV-2 From an Infected Mother to Her Newborn. JAMA. 2020;323(18):1846-1848.

127. Zeng $\mathrm{H}, \mathrm{Xu} \mathrm{C}, \mathrm{Fan} \mathrm{J}$, et al. Antibodies in Infants Born to Mothers With COVID-19 Pneumonia. JAMA. 2020;323(18):1848-1849.

128. Kimberlin DW, Stagno S. Can SARS-CoV-2 Infection Be Acquired In Utero?: more Definitive Evidence Is Needed. JAMA. 2020. doi:10.1001/jama.2020.4868

129. Hosier H, Farhadian SF, Morotti RA, et al. SARS-CoV-2 infection of the placenta. J Clin Invest. 2020;130(9):4947-4953. doi:10.1172/JCI139569

130. Baud D, Greub G, Favre G, et al. Second-Trimester Miscarriage in a Pregnant Woman With SARS-CoV-2 Infection. JAMA. 2020;323(21):2198-2200. doi:10.1001/jama.2020.7233

131. Penfield CA, Brubaker SG, Limaye MA, et al. Detection of severe acute respiratory syndrome coronavirus 2 in placental and fetal membrane samples. Am J Obstet Gynecol MFM. 2020;2(3):100133. doi:10.1016/j.ajogmf.2020.100133

132. Hecht JL, Quade B, Deshpande V, et al. SARS-CoV-2 can infect the placenta and is not associated with specific placental histopathology: a series of 19 placentas from COVID-19-positive mothers. Mod Pathol. 2020;33(11):2092-2103. doi:10.1038/s41379-020-0639-4

133. Menter T, Mertz KD, Jiang S, et al. Placental Pathology Findings during and after SARS-CoV-2 Infection: features of Villitis and Malperfusion. Pathobiology. 2021;88(1):69-77. doi:10.1159/ 000511324 
134. Taglauer E, Benarroch Y, Rop K, et al. Consistent localization of SARS-CoV-2 spike glycoprotein and ACE2 over TMPRSS2 predominance in placental villi of 15 COVID-19 positive maternal-fetal dyads. Placenta. 2020;100:69-74. doi:10.1016/j. placenta.2020.08.015

135. Algarroba GN, Rekawek P, Vahanian SA, et al. Visualization of severe acute respiratory syndrome coronavirus 2 invading the human placenta using electron microscopy. Am $J$ Obstet Gynecol. 2020;223(2):275-278. doi:10.1016/j.ajog.2020.05.023

136. Landes $M$, van Lettow M, Nkhoma E, et al. Low detectable postpartum viral load is associated with HIV transmission in Malawi's prevention of mother-to-child transmission programme. J Int AIDS Soc. 2019;22(6):e25290. doi:10.1002/jia2.25290

137. Saminathan M, Singh KP, Vineetha S, et al. Virological, immunological and pathological findings of transplacentally transmitted bluetongue virus serotype 1 in IFNAR1-blocked mice during early and mid gestation. Sci Rep. 2020;10(1):2164. doi:10.1038/ s41598-020-58268-0
138. Vivanti AJ, Vauloup-Fellous C, Prevot S, et al. Transplacental transmission of SARS-CoV-2 infection. Nat Commun. 2020;11 (1):3572. doi:10.1038/s41467-020-17436-6

139. Groß R, Conzelmann C, Müller JA, et al. Detection of SARS-CoV-2 in human breastmilk. Lancet. 2020;395(10239): 1757-1758. doi:10.1016/S0140-6736(20)31181-8

140. Wang K, Chen W, Zhang Z, et al. CD147-spike protein is a novel route for SARS-CoV-2 infection to host cells. Signal Transduct Target Ther. 2020;5(1):283. doi:10.1038/s41392-020-00426-x

141. Daly JL, Simonetti B, Klein K, et al. Neuropilin-1 is a host factor for SARS-CoV-2 infection. Science. 2020;370(6518):861-865. doi:10.1126/science.abd3072

142. Smieszek SP, Przychodzen BP, Polymeropoulos MH. Amantadine disrupts lysosomal gene expression: a hypothesis for COVID19 treatment. Int J Antimicrob Agents. 2020;55(6):106004. doi:10.10 16/j.ijantimicag.2020.106004

\section{Publish your work in this journal}

Infection and Drug Resistance is an international, peer-reviewed openaccess journal that focuses on the optimal treatment of infection (bacterial, fungal and viral) and the development and institution of preventive strategies to minimize the development and spread of resistance. The journal is specifically concerned with the epidemiology of antibiotic resistance and the mechanisms of resistance development and diffusion in both hospitals and the community. The manuscript management system is completely online and includes a very quick and fair peerreview system, which is all easy to use. Visit http://www.dovepress.com/ testimonials.php to read real quotes from published authors. 